\title{
No Ivory Tower: The Administration of a College or University Archives
}

Mr. Wilson has been an archivist in the War Records Section at National Archives; archival consultant to the Allied Commission Archives and deputy director of the Records Administration Seminar for Allied Force Records Administration in Rome, Italy; and archivist and records administrator, Fisk University.

$\mathrm{T}$ HERE are those who think of a college or university archives as miscellaneous, jumbled old records stored away in a library room, and used only when the library wants to exhibit a program commemorating a speech given by a visiting dignitary. In such thinking, it follows naturally that the archivist is the person who tosses in or takes out these odd items in the time that can be spared from more important duties-teaching, or running the library. Nothing could be further from the truth!

The archives division is a service unit on the same administrative level as the library. It contains organic bodies of records, systematically arranged and made available to the officers of administration and instruction. Its primary function is to preserve the institution's official records for possible evidential values-administrative, legal or research.

Generally, the archives comprise: (I) records of departmental and administrative offices (correspondence files); (2) minutes of trustee, faculty and committee meetings; (3) samples of student notes and faculty lecture notes; (4) examinations; (5) official and student publications; (6) records of student organizations and classes; (7) samples of discarded texts; (8) pictures of university people and places; (9) blueprints of campus

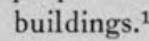

It is not unusual for other members of the

1 A discussion of college archives is contained in the author's "Archives in Colleges and Universities: Some Comments on Data Collected by the Society's Committee on College and University Archives," American Archiv. ist, $13: 343-50$, October 1950 . staff to look at the archivist and ask, often with lifted eyebrows, "And you devote all your time to that?" Anyone who is or has been a college archivist can say, ex cathedra, that eight to ten hours a day spent in processing records, while at the same time inaugurating and explaining his program, do not make for the peaceful life of the cloister.

Basic matters which occupy his time are: accessioning, cleaning the records, rehabilitation, packing and shelving, analysis and description, preparation of finding media, records administration, reference service, publications, public relations, reports, correspondence, and administrative planning. In no other archives, with the exception of some church or state with wholly inadequate archival programs, is one person supposed to perform all these duties.

As the first essential in initiating his program, the archivist establishes an objective to attain and to this end he might draw up a plan for each year. For the first year his plan could be, with variations, roughly outlined as follows:

I. Goal for the Year

A. Draw up charter, or plan of organization, for the archives. ${ }^{2}$

B. Search all attics, basements, closets, or other places where there is a possibility that old records may have been stored and forgotten.

C. Begin getting understanding of records retirement over to officers of administration and instruction.

\section{Building the Institution's Archives}

A. Survey records in administrative and departmental offices.

B. Compile results of survey into work plan.

I. Remove records from various storage places to workroom.

${ }^{2}$ See end of article for model charter or plan of organization. 
2. Survey collected records to ascertain whether or not original order (respect pour les fonds) has been preserved.

3. First retirement of records directly from offices.

\section{Development of Program}

A. Provide initial training in basic archival economy to assistants. (See Staff.)

B. Enroll institution as member of Society of American Archivists. (The journal, American Archivist, provides valuable information and forms the nucleus for the archival library.)

C. Request the establishment of an Archives Council or Committee. In the normal course of events, this group keeps informed of the archivist's aims and progress, and helps interpret the meaning of archives to the rest of the college community. It is essential that the archival program have the solid backing of as many influential people as possible. Hence, it is suggested that the council have as permanent members: the president (chairman), the dean (co-chairman), the librarian and the archivist (ex officio). Serving for one year each would be a departmental head and a professor. In a large university where there are a number of deans, the executive dean might be the permanent member with the other deans serving in rotation as do the departmental heads and professors.

\section{Relations with Officers of Administration and Instruction}

A. Hold individual conferences with administrative officers and departmental heads.

B. Send out circular letter with first instructions on retirement of noncurrent records.

\section{Working Needs}

A. Staff.

I. If budget is limited, recruit student assistants.

a. They cannot work on confidential records.

b. It is more important that they be historically-minded than that they be history majors.

2. Office assistant (part time if necessary).

B. Equipment.

I. For office-desk, telephone, filing cabinets.

2. For archives-clean, dry workroom; chairs, two or more large work tables; adequate shelving space; transfer cases; acid-free document cases; gummed printed labels.

\section{Supplies.}

I. Pencils, desk set, paste, archives letterhead, rubber stamps, duplimats, magnifying glass, etc.

The archivist should keep in mind that no plans, however good, can be put into effect unless ample room is provided for the expansion of the archives.

It appears to be extremely difficult for some administrators to realize that any archival program comes to nought if sufficient space is not available. When one considers that the average four drawer filing cabinet contains twelve thousand documents which, packed and shelved in document cases, take up six and a half or more linear feet, it is easy to see why space is the archivist's perennial worry. If the idea is carried a bit further and an estimate made of the number of offices and departments each retiring two or more file cases of non-current records per year, it at once becomes obvious that one or two small rooms will not suffice for shelving space.

In addition, there remains the matter of working space. Often the archivist must not only restore records to their original order, but arrange them in a logical order for the first time. College secretaries have been known to file car keys, personal letters, rose bush catalogs and, sometimes, sandwiches in the official files. Many do not have filing systems, but filing whims. When these depart, new secretaries introduce new whims; and the archivists, as well as the offices they serve, suffer as a consequence. (Happy and glorious be the day when institutions insist that stenographers and secretaries know filing as well as shorthand and typing!)

Improperly filed material is only one of the reasons why the archivist must demand adequate working space. The whole business 
of processing the records-examining, cleaning, sorting, rearranging-requires room enough for the records to be spread out in orderly fashion that they may be reassembled as organic bodies.

A third space need is that for temporary storage. This would accommodate records that have been retired in order to release space for current records, and at the same time insure their safety from destruction while awaiting processing.

Insuring the safety of the records is one of the archivist's major functions. In the average college, there are huge gaps in the records, caused no doubt by the tendency of incoming officers to throw out the files of their predecessors. Unfortunately, these lacunae occur too frequently in such substantial series as high level correspondence, trustee and faculty minutes, and reports. These and other records are needed as complete bodies for research in the fields of educational standards, curriculum development, policies of faculty control, or the impact of an institution on the development of other colleges and universities.

Another contributing factor in the loss of important records is the peculiar form of myopia which seems to blind some university officials to the fact that they could benefit by looking through the non-current files created by former incumbents of their offices. Apparently, they fail to realize that their own contributions can only be measured by comparison with the accomplishments of their predecessors and successors.

On the other hand, it may be that college officers never think of the fact that they are making educational history-good or bad. Just as there is no reason to assume that soldiers, fighting for their lives, are aware that they are making history, so there is no reason to suppose that administrative officials, busy with current duties, can know to what extent their records may be called upon in later years by educators, historians, sociologists, statisticians, genealogists, biographers, and a variety of other users whose work constitutes research. ${ }^{3}$

The newly designated college or university archivist who is not an alumnus of the stack area at National Archives, or who has

${ }^{3}$ Brook, Philip C., "Selection of Records for Preservation." American Archivist 4:221-34, October I940. taken no courses in archival administration, is sometimes at a loss as to the proper way in which to arrange his materials. Usually, he finds that the simplest way is the best and merely assigns a record group number to the various offices and departments. After the packing and shelving is done, the labels on the front of the document cases might appear somewhat like this:

BLANK COLLEGE ARCHIVES

OFFICE OF THE PRESIDENT

RG: I

Correspondence File
Abbott-Avery
$(1865-1866)$

Or, instead of Correspondence File, it may be Faculty and Staff, Contracts, or other identifying words. The important thing is that the organic unity of the records is preserved. Later it may be desirable to consolidate some of the records within an office and work out a more elaborate arrangement. Only time and experimentation will point the way.

Another confusing matter to the beginning archivist is that of records disposal. Unlike National Archives and some government agencies, a college or university archives has no manual for the periodical destruction of records which have outlived their usefulness.

The president, or some other administrative officer may have written a memorandum which establishes a precedent or the policy of a department. A trustee, in the middle of a generally inconsequential letter, may have made a statement vital to the interests of the institution. Hence, the archivist retains nearly everything until he has served long enough to estimate without grievous error what should or should not be destroyed.

At the outset, practically the only documents that can be destroyed with any degree of assurance are certain records of the business office which have passed the statute of limitations-student receipts, bills, vouchers, and cancelled checks. Samples of these, nevertheless, are preserved for exhibition fifty or a hundred years later. Even applications are worth retaining. A now struggling person may later become famous, and his biographer would be interested in knowing that he was once refused a position at the institution.

To facilitate his reference service, the archivist may have a card file containing in- 
formation found in the records. Possibly an entry may appear as illustrated:

\section{BLANK COLLEGE ARCHIVES} REFERENCE SERVICE

Date Received $9 / 4 / 51$

Inquiry: When was Blank's motto officially adopted

Inquirer: John Doe

Position: Writer

Location: 442 Angel Avenue, Chicago, Illinois

Found: $x$

Date answered: $10 / x / 5 \mathrm{I}$

Multilithed, these cards can be filled out in a minimum of time, and the information found typed on the reverse side so that if the inquiry is repeated the archivist or his assistant is saved the trouble of searching the records again. When report-making time comes around this card file is indeed a boon. At a glance the archivist can see how many reference requests were answered in any given month, from whence they came, and something of their general nature.

Professor Kenneth Hooker, in the 1949 Winter Bulletin of the American Association of University Professors, has an article entitled "College Teaching: The Loneliest Profession in the World." 4 With all due respect to Mr. Hooker, the full time college archivist is lonelier. The faculty member at least has others in his department who can understand his aims and aspirations. The archivist seldom has anybody-even the people assisting him are not generally aware of the ramifications of the program he is trying to develop. On his shoulders, and his alone, rests the final responsibility for giving his department stature.

The professors often regard him as an administrative frill, while the trustees are only too prone to consider him a needless expense. Both faculty and trustees are grossly in error.

Economically, the archives effect a saving in office space, filing equipment, administrative time, and not infrequently money. How true is this? Offices keep records that are referred to not more than two or three times a year because there is no place to put them. When the file cases are full, one of two things happens. Either valuable records are thrown away, or new file cases are ordered. If the former occurs the entire institution loses. If

Ibid. p. 643-50. the latter, several results ensue. Office space is lost for one; and good file cases cost over a hundred dollars for another. The document cases used by the archivist cost approximately forty-three cents apiece, and twenty document cases will hold the contents of the average four drawer file cabinet. There is, to point out the obvious, a substantial difference between a hundred dollars and eight dollars and sixty cents.

It is impossible to gauge the number of man hours lost each year by administrators replying to letters unimportant in themselves, but requiring answers for reasons of policy. Rare is the president or dean who has not received letters asking when this or that building was erected; or when Dr. Whozis played on the football team and what position he played. Communications of this nature are properly transmitted to the archives for prompt and correct answering.

Non-current records are also useful in the settlement of land disputes, suits, and many other legal entanglements into which the college or university may be drawn. Much needed financial assistance is often lost because someone has destroyed the record of the name of a donor and the terms of his donation. When this happens the money is put in a general scholarship fund and awarded according to fancy or expedience. Regardless of his importance or unimportance in the world of affairs, a donor likes to see his gift listed in the institution's catalog, and if he doesn't-!

At the risk of belaboring a point, it might be added that hard-headed business firms and banks do not establish their archives because they need or want a frill or a needless expense.

While most archives eschew any detailed work with record copies of printed material, a college or university archives may find it necessary. Student newspapers, yearbooks and other publications, the alumni bulletins, catalogs, and handbooks either supply or give clues to the whereabouts of much information that has been lost with the destruction of vital records. In addition, they enable the archivist to detect the errors that have inevitably crept in with the rewording of essential information from year to year.

Many of the smaller institutions, and a number of the larger ones are unable to say with any exactitude just when certain depart- 
ments were formally established; to give any extensive information about past presidents and their accomplishments; or to measure the raising of their standards from the beginning to the present. Surprisingly, many schools are in error even concerning the commencements that have been held. Some make this mistake because they date commencements from the year in which the college was founded, and others because they are in ignorance of the year in which the first class graduated.

Apart from detecting errors, the archivist finds in official publications, and those published under the aegis of the institution, interesting items about the alumni who have achieved prominence in their fields. When he collates such items and sends them to the people concerned-the societies headed, social activities, musical triumphs, athletic prowess - the rewards are well worth the trouble.

To mention but a few of these rewards: the program receives increased support from the alumni; the archivist's knowledge of the university he serves is greatly enlarged; much ready reference is at hand; and the alumni on whose aged brows the laurel is withering accept with gratitude the opportunity of reliving the days when life was not so complex and burdensome.

From the point of view of the institution, which is of necessity pragmatic, the alumni comprehending that other than their academic records are preserved are more inclined to respond to appeals for contributions. And, such is the vanity of man, some might insure continued preservation by means of gifts and legacies. The archivist, however, makes it clear, through the alumni publications, that all graduates have mementos of their student days in the archives.

Time and again researchers and authors discover that some person in whom they are interested once appeared at Blank in 18-. They then write asking the exact date of the appearance, text of the address, occasion, audience reaction, and other pertinent facts. The answers to these questions are not commonly found in the official records, but the various publications are gold mines of information.

Though such handling of printed material normally is, or should be, the function of the library, the archivist, in view of the foregoing, still finds it advantageous to set up a card file noting information gathered from the college's publications.

Dealing with a wide variety of subjects, cards might have headings reading: Benefactors; Distinguished Visitors; Presidents (of the college); Howler's Hall; Roe, Richard. For example:

BLANK COLLEGE ARCHIVES

\section{BENEFACTORS}

Rices, Joseph-Detroit, Michigan

Donated $\$ 1,000$ for band instruments and uniforms. Campus Cynic: Oct. 18, 1899 . p. 10.

Alumni Bulletin: Dec. 1899. pp. 2, gf.

Filed alphabetically and cross referenced, a card file of this sort is invaluable. Besides supplying the demands noted above, it is a help to the college historian who has to rely on faulty memories in the absence of official documentation; to the Director of Public Relations who will appreciate having some factual basis for his releases; and to the Alumni Secretary who will discover material that enlivens the alumni journal. In short there are few, if any, departments or offices that will not at some time or another have recourse to information found only in the university publications.

The library is fairly well established as being the heart of the campus, but it will take some time before schools awaken to the fact that the archives contain the life blood of the institution. The archivist of one of the large eastern universities recently wrote to the effect that college and university archivists must "educate their masters." ${ }_{5}$ An undertaking of this sort requires the courage of the lion and the meekness of the dove. The archivist is torn by conflicting emotions, and feels with Hippocrates that while the occasion is instant, the decision is difficult and the experiment perilous.

Professional or non-professional, the person undertaking the establishment of a college or university archives will encounter a number of problems completely outside his previous experience, and he will do well to begin with a goodly stock of patience. This statement does not stem from defeatism, but from the sound knowledge that one cannot plant a

${ }^{5}$ Letter from Dr. Leonidas Dodson, Archivist of the University of Pennsylvania, to the writer, February 26, $195 \mathrm{I}$. 
tree today and expect to sit in the shade tomorrow.

Voices all over the country are crying in the wilderness, "How can I get the institution to recognize the value of an archival program?" This question causes the archivist to explore all avenues even approaching this so devoutly hoped for consummation.

If his colleagues are interested enough to ask about his work, they are invited to see what has been done, and told what is being attempted. Talks to the faculty as a body are rarely successful, because they are too condensed to be fully appreciated. More, it requires a great deal of persuasion to convince some professors that non-current records will not be locked in a vault and made forever inaccessible; an equal amount to convince others that their restricted records will not be available to anyone else without authorization; and an unconscionable amount to get it over to the possessive ones that the records belong to the office and not to the man in the office.

One of the most curious phenomena to be seen on a campus is the administrator or professor who knows that several loquacious typists have read his letters, yet who becomes a victim of hypertension when he learns that the archivist might chance to read them in the far-distant future. If the archivist can gradually uproot these phobias and instill the correct ideas, time is not wasted.

Of equal importance is the attracting of student attention. Other administrators may, but the archivist should never forget that the student of today is the alumnus of tomorrow. Undergraduate attention is most easily engaged by articles in student publications telling the history of buildings; recalling traditions that have fallen into disuse; and permitting, even urging, students to use nonrestricted material from the archives for the writing of term papers, themes, and theses and dissertations. This last device has been used fairly extensively, and it has been found that the instructor's interest is stimulated when footnotes continually appear with some mention of the institution's archives.

The showing of exhibits is, of course, standard operating procedure. As illustration, some excellent archival exhibits at the University of Michigan during the summer of I949 included:

I. "Hurry Up Yost," showing photographs, plaques, cartoons and programs selected from the records of the Athletic Association; all dramatizing the career of the great Michigan coach.

2. "Student Publications," an exhibit of student literary magazines, newspapers, annuals and yearbooks from the earliest (and sometimes defunct) to current publications.

3. "A Century of Commencements" displaying commencement programs, beginning with the first in 1845 , diplomas, class day programs, photographs of academic parades, and other materials from the archives showing how ceremonies had changed with the passage of time.

The possibilities are unlimited.

Naturally the alumni too are interested in the establishment of any new departure at their alma mater, and it is incumbent upon the archivist to write articles for the alumni journal outlining the meaning, aims, and progress of the archives. Reportorial work of this nature often brings in material of interest-diaries of student days, lecture notes, photographs, or missing copies of publications. If the student has remained at the college as a professor, it is just possible that, as a professor emeritus, he might return some of the records belonging to the school.

Beyond the strictly college or university relationships, the archivist establishes and maintains professional and scholarly affiliations that are mutually beneficial. ${ }^{6}$ Archivists as a tribe are not selfish with ideas and are usually willing to offer, or accept solutions to problems. Those who serve national, state, church, business, and various institutional or societal archives are quite willing to give the benefit of their experiences and send reports of their activities. Some reciprocity is no more than courteous.

To use up his spare time, and afford himself a change of pace, the archivist might give guest lectures; collaborate with the librarian on planning a college museum; or write articles on subjects taken from the non-restricted records. It is sometimes feared that others on the faculty may resent the latter activity because the archivist has ready access to the records. Ergo, it must be iterated and reiterated that records in this category are available to students, faculty,

6 American Archivist 14:33-45, January 1951. Dr. Brooks' presidential address to the Society of American Archivists. 
biographers, genealogists, or to any other serious, authorized person.

Pitfalls in this supposedly secluded life are abundant. From medieval times until the present professors have traditionally taken derogatory slaps at the value of each other's work. Nevertheless, during the journey from the kindergarten to the Ph.D. they did learn that departments other than their own had a place in the school. The archivist, however, like a literate sitting duck, makes a wonderful target.

When his step begins to falter, he is solaced if, framed and hanging on the wall over his desk, are the words of Sir Hilary Jenkinson, Deputy Keeper of the Records for England:

"The Archivist's career . . . is one of service. He exists in order to make other people's WORK possible, unknown people for the most part and working very possibly on lines equally unknown to him; some of them in the quite distant future and upon lines as yet unpredictable. His Creed, the Sanctity of Evidence; his Task, the conservation of every scrap of Evidence attaching to the Documents committed to his charge; his Aim, to provide, without prejudice or afterthought, for all who wish to know, the Means of Knowledge."7

\section{ARCHIVES CHARTER or PLAN OF ORGANIZATION}

I. $N A M E$. Archives is hereby established as the official archival agency of the University (or college).

II. OBJECTIVES. The objectives of the Archives shall be: the collection, preservation and administration of the official records of the University; and the development of standards for the making, care and administration of archives at - .

III. ARCHIVES COUNCIL. The University Archives shall be governed by an Archives Council of five persons, consisting of the President, the Dean of the University, the Librarian, the Head of a Department, and a Faculty Member. The Departmental Head and the Faculty Member will change every year. The President shall be

The English Archivist: A New Profession. London, H. K. Lewis \& Co. Ltd., r948, p. 30-31. the Chairman of the Council, and the Dean Co-chairman. The Archivist shall be a member ex officio, and shall serve as Secretary.

IV. FUNCTIONS OF ARCHIVES COUNCIL. The Archives Council shall have the authority to make policies regulating the Archives; to control the expenditure of such funds as may be appropriated for equipment and maintenance; to accept gifts, bequests, and endowments for purposes consistent with the aims of the Archives; to make necessary reports of receipts, disbursements, work and needs to the President; and to adopt policies and projects designed to fulfill the duties and attain the objectives of the Archives.

V. THE ARCHIVIST. The active management and administration of the Archives shall be vested in the Archivist, who shall be qualified by professional training or experience in archival work at the time of his appointment. The Archivist shall formulate rules and regulations, under existing policies, for the use of the University Archives.

VI. FUNCTIONS OF THE ARCHI$V I S T$. The Archivist shall perform all duties in connection with the administration and development of the archives, so as to achieve the purposes of its creation.

VII. OPERATION OF THE ARCHIVES.

A. Transfer of Records. On behalf of the University, the Archivist is authorized to negotiate for the transfer of and to receive University Archives from the custody of any office of administration or instruction or other record-creating divisions.

B. The Archival Program. The Archivist shall collect, arrange and make available to authorized persons, at reasonable times, in the office of the Archives, all obtainable archival materials relating to the operation and history of - He shall carefully protect and preserve them from deterioration, mutilation, loss or 
destruction. $\mathrm{He}$ shall keep the official archives in his custody in such arrangement and condition as to make them accessible for convenient use, and shall permit them to be inspected, examined, abstracted, or copied at reasonable times under his supervision, by any authorized person. He shall make arrangements for the furnishing of certified copies thereof on payment in advance of fees as prescribed by the Council.

C. Release of Non-current Records. Any record-creating division at is hereby directed and empowered to release to the University Archivist for preservation and administration such university records legally in its custody as are not needed for the transaction of the current business of the office, whenever the Archives is willing and able to receive and call for them.

Whenever such transfer is made, the Archivist shall transmit to the office from which the records are transferred a list in which such records are described in terms sufficient to identify them. This list shall be filed and preserved in said office.

All University Archives of any division shall, upon the termination of the existence and functions of that office, be transferred to the custody of the Archives, unless otherwise directed by the Archivist.

The Archivist, in person, or through a deputy, shall have the right of reasonable access to and examination of all current University records.

D. Records Administrator. In addition to purely archival functions, the Archivist shall also serve as Records Administrator. $\mathrm{He}$ shall examine into and report to the Council on the condition of current records.
$\mathrm{He}$ shall cause such actions to be taken by their custodians as may be necessary to put them in the condition needed to preserve them from misplacement, loss or destruction. $\mathrm{He}$ shall promote better care of the files and advise with records-creating offices regarding:

1. the disposal of useless archives in their custody;

2. the record of archives belonging to their offices;

3. the delivery of archives to their successors in office;

4. the adoption of sound practices relative to the use of durable paper and ink;

5. other desirable practices which which will facilitate better use of current files and orderly retirement to the Archives of noncurrent records.

The Archives shall, at stated intervals, issue circular letters on the procedures to be followed in the management of records.

VIII. UNIVERSITY POLICY. The policy stated above relates to the official records of the University.

IX. ARCHIVES OTHER THAN UNIVERSITY ARCHIVES. Archives of other agencies, organizations, or the personal papers of individuals entrusted to the custody of the University shall be governed and administered in accordance with the strictest archival practices. Regulations and restrictions governing their use shall be worked out by the Archivist in conjunction with the Archives Council. As non-official archives are processed, guides will be issued with a statement of policy included.

X. OFFICIAL ESTABLISHMENT. The foregoing shall be in full force and effect from and after

(date)

APPROVED :

Archives Council, $-\longrightarrow$ (date)

Board of Trustees, - $\longrightarrow$ (date) 